\title{
Public attitudes toward corneal donation in northern Jordan
}

This article was published in the following Dove Press journal:

Clinical Ophthalmology

\section{Mera F Haddad' \\ Omar F Khabour' \\ Karem H Alzoubi ${ }^{2}$ \\ May M Bakkar'}

'Faculty of Applied Medical Sciences, Jordan University of Science and Technology, Irbid, Jordan; ${ }^{2}$ Faculty of Pharmacy, Jordan University of Science and Technology, Irbid, Jordan

Correspondence: Mera F Haddad Faculty of Applied Medical Sciences, Jordan University of Science and Technology, PO Box 3030, Irbid 221। 0 , Jordan

Tel +962 27201000

Email mfhaddad@just.edu.jo
Purpose: The aims of this study were to assess the knowledge and attitude toward corneal donation among Jordanian population and to report the reasons which may influence subject's decision and attitude toward corneal donation.

Methods: A self-designed questionnaire was developed. The participants were asked about reasons for both willingness and unwillingness to donate their corneas. These reasons were stated in the questionnaire and the participants had to express their agreement by one of five options: strongly disagree, disagree, neutral, agree, or strongly agree.

Results: A total of 500 participants (218 males and 282 females) completed the questionnaire. The average age $( \pm \mathrm{SD})$ of the study participants was $32.8( \pm 11.7)$ years. About $67.2 \%$ of the subjects were willing to donate their corneas, whereas $32.8 \%$ were not willing to do so. The main motive for willingness was doing a good deed by helping others to see. On the other hand, fear of the body being treated badly and that other organ might be taken than the ones specified for donation were the main reasons for unwillingness to donate corneas. The age of participants, gender, and the monthly income did not significantly influence the willingness to donate $(P>0.05)$. However, the level of education had a significant influence on people's decision to donate their corneas.

Conclusion: Many Jordanians have positive attitude toward corneal donations. Ethical factors need to be addressed to promote for corneal donation. In addition, increasing the awareness of donation and its benefits may help increase the supply of corneal tissues.

Keywords: corneal donation, willingness, Jordan

\section{Introduction}

Corneal blindness accounted for 4\% of global blindness, as estimated in $2010 .{ }^{1}$ According to the WHO census published in 2018, corneal opacities accounted for $5.1 \%$ of the world's blind population and considered the fourth most common cause of blindness globally. ${ }^{2}$ Causes of corneal blindness reported in the ophthalmic literature include corneal ectasia, such as keratoconus, bullous keratopathy, corneal dystrophies, xerophthalmia, corneal infections due to Chlamydia trachomatis and other microbial infections, ocular ulceration, and ocular trauma that involve the cornea.

In the Middle East, corneal blindness was listed as the fourth cause of blindness among children after other causes of blindness: retinal degeneration, congenital cataract, and congenital glaucoma. ${ }^{3}$ In Jordan, Al-Bdour et al reported in a hospital-based study that corneal opacification was the fourth most common cause of unilateral and bilateral blindness with higher occurrence among patients younger than 25 years old. They also reported that corneal blindness accounts for $13.8 \%$ of total cases of blindness in the same study. ${ }^{4}$

Corneal transplantation is one of the most common successful organ transplant procedures performed worldwide to treat corneal blindness and restore vision in affected 
patients. The first successful attempt of human corneal transplant started early in the 19th century by Edward Zirm. ${ }^{5}$ Since then, the procedure has been improved by evolving new surgical techniques ranging from full thickness penetrating keratoplasty to partial thickness lamellar keratoplasty that involves removing and replacing of selective damaged corneal layer/s. ${ }^{5-10}$ Along with improvements in corneal imaging, surgical instrumentation, and preoperative patient's care, the success rate of the corneal transplantation surgery has been reported to be as high as $80 \%$ worldwide. ${ }^{11-13}$

Despite the high success rate of corneal transplantation, the available number of corneal grafts is reported to be lower than the actual need for corneal graft. ${ }^{14}$ This issue is documented worldwide in both developed and developing countries and is mainly related to shortage in corneal tissue donation. Al-Bdour et al also pointed that corneal donation is very rare in Jordan and that there is a long waiting list of patients who need corneal graft. ${ }^{4}$

Factors limiting corneal donation have been investigated extensively and attributed mainly to refusal to donation by either the person or their families. ${ }^{14}$ Other factors include lack of consent from deceased patients or their relatives, medical contraindications to procurement such as infections or low corneal endothelial cell count, and logistical issues related to approaching deceased patients' relatives. ${ }^{14-16}$

Many reports have addressed knowledge of different populations and their attitudes toward corneal donation. ${ }^{17-22}$ Factors that affect subject's decision and unwillingness to corneal donation were determined by other studies, which included insufficient knowledge and awareness of the public about donation; ethical, religious, and cultural issues; and beliefs concerning death and mortality. ${ }^{15,20,23-26}$

To the best of our knowledge, this is the first study to assess the level of knowledge and attitude toward corneal donation among Jordanians, where similar results have not been reported from the population of this study. In addition, factors that might influence the willingness and unwillingness to donate the corneal tissue will be investigated. The findings obtained from the study are of paramount importance to target these issues and act to promote levels of awareness of corneal donation among the public in Jordan, which may improve quality of life among patients with corneal blindness.

\section{Methods}

\section{Study design}

A cross-sectional study was performed using a structured questionnaire that was developed to obtain information about attitude toward corneal donation and to identify factors that might affect corneal donation in Jordan. The study was conducted in northern Jordan between September 2017 and January 2018.

\section{Participants}

The study participants were selected randomly from the general community population in the north of Jordan. Participants aged $\geq 18$ years were invited to complete a selfadministered questionnaire on knowledge of corneal donation and reasons of willingness and unwillingness toward corneal donation. Participants were selected randomly from general public places including shopping malls, bus stations, and universities.

\section{Ethics approval}

The ethics approval for conducting this study was granted by the Institutional Review Board committee at Jordan University of Science and Technology. Informed written consent was obtained from all participants prior to their participation in the study and all study methodologies complied with the guidelines of the Declaration of Helsinki.

\section{Exclusion criteria}

People with any abnormal cognitive ability that may affect their logical responses were excluded from the study.

\section{The questionnaire}

The questionnaire was developed by the research team for the purpose of this study. The questionnaire was initially designed by a focus group that consisted of a group of practicing optometrists and public health researchers. Possible reasons for willingness and unwillingness toward corneal donation were discussed, verified, drafted, and documented.

The questionnaire was then assessed for clarity and ease of comprehension in a pilot group consisting of 25 subjects selected randomly from the general population. Comments and remarks from the pilot group were taken into consideration prior to using the final version of the questionnaire. The data from the pilot group were not included in the final data analysis.

The final version of the questionnaire consisted of 3 parts and included a total of 12 questions: 1) the first part acquires data on sociodemographic characteristics of the participants, such as age, gender, level of education, and economic status; 2) participants were then asked to answer a series of questions related to knowledge about corneal donation; and 3) finally, participants were asked to express their agreement 
with suggested reasons for willingness and unwillingness toward corneal donation. Participants had to express their agreement with each reason of willingness and unwillingness using a 5-point Likert scale (from 1: strongly disagree to 5: strongly agree). Listed reasons included ethical, religious, and social reasons, which may influence the subject's decision regarding corneal donation.

In order to assess the reliability of the developed questionnaire, a random sample was used for test-retest reliability. Twenty subjects were approached to fill out the questionnaire, and the same subjects were interviewed again after 1 week to assess the intra-subject reliability of answers.

The questionnaire was then administered to a larger sample $(n=500)$ of the population in the north of Jordan. The questionnaire was administered by the same surveyor. A brief explanation of the purpose and significance of the study was introduced to each participant prior to their participation. The surveyor also clarified some concepts related to corneal tissue donation to ensure that all participants had the same level of comprehension of the questions and to establish consistency in acquired responses.

\section{Statistical analysis}

Data were analyzed using SPSS software version 21.0 (IBM Corporation, Armonk, NY, USA). Descriptive statistics including frequencies and percentages were calculated to summarize the categorical data. Univariate comparisons between attitude toward corneal donation with age and income were done using independent $t$-test, and chi-squared test was applied for the categorical variables (gender and level of education). A $P$-value of $<0.05$ was considered statistically significant.

\section{Results}

\section{Demographic characteristics of participants}

A total of 500 participants ( $43.6 \%$ males and $56.4 \%$ females) completed the questionnaire. The average age $( \pm \mathrm{SD})$ of the study participants was $32.8( \pm 11.7)$ years and ranged from 18 to 74 years. Demographics of all participants are shown in Table 1.

\section{Awareness and general attitudes toward corneal donation}

Figure 1 shows that the majority of the participants $(88.0 \%)$ had heard about corneal donation. Willingness to donate the cornea after death was confirmed by $67.2 \%$, and a higher percentage $(82.8 \%)$ would encourage people to donate.
Table I Participants' characteristics $(n=500)$

\begin{tabular}{|l|l|}
\hline Variable & No (\%) of respondents \\
\hline Gender & \\
\hline Male & $218(43.6)$ \\
\hline Female & $282(56.4)$ \\
\hline Age group (years) & \\
\hline I8-29 & $272(54.4)$ \\
\hline $30-50$ & $188(37.6)$ \\
\hline$>50$ & $40(8.0)$ \\
\hline Smoking & \\
\hline Non-smokers & $542(70.5)$ \\
\hline Smokers & $227(29.5)$ \\
\hline Education level & \\
\hline Illiterate/elementary & $44(8.8)$ \\
\hline High school & $136(27.2)$ \\
\hline $\begin{array}{l}\text { Higher education } \\
\text { Bachelor } \\
\text { Graduate degrees }\end{array}$ & $293(58.6)$ \\
\hline Income (JOD) & $27(5.4)$ \\
\hline$<500$ & $27 I(54.2)$ \\
\hline $500-I, 000$ & $178(35.6)$ \\
\hline$>I, 000$ & $5 I(10.2)$ \\
\hline Abbrevion & \\
\hline
\end{tabular}

Abbreviation: JOD, Jordanian Dinar.

More than half of the participants (54.8\%) agreed to report their willingness on the driver's license.

\section{The association between willingness to donate the cornea and the study variables}

The influence of the study demographics on the willingness of the participants to donate their corneas is shown in Table 2 . Age, gender, and monthly income did not significantly influence respondents' willingness to donate their corneas after death ( $P>0.05$ for all variables). However, level of education had a significant effect $(P=0.00)$.

\section{Responses regarding willingness and unwillingness to donate the cornea after death \\ Willingness to donate the cornea}

Responses about willingness to donate corneas were investigated by asking participants to express their agreement with clear statement related to willingness. The data from the participants' responses were based on their level of agreement with each statement represented in 5-point Likert scale (from 1: strongly disagree to 5 : strongly agree).

Most of the willing participants agree and strongly agree that corneal donation is a gift of vision and that it should be promoted 


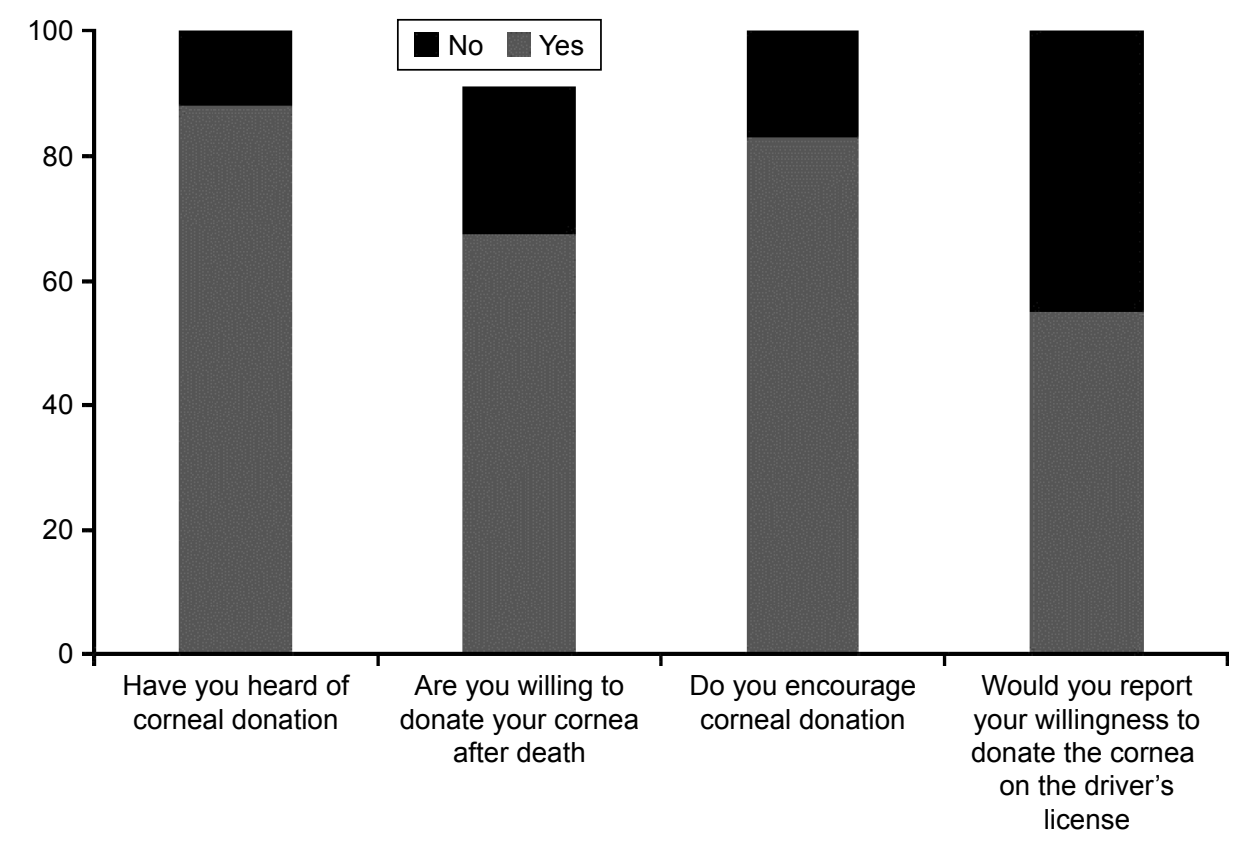

Figure I Awareness and general attitude toward corneal donation among the study participants.

worldwide. Religious beliefs that the life of a person belongs to God and not to the person's family were agreed upon by the majority of willing participants. Although many participants thought that the family of the deceased should be financially reimbursed to promote donation, an equal percentage (26.6\%) disagreed on this argument. Table 3 summarizes participants' responses regarding willingness to corneal donation.

\section{Unwillingness to donate the cornea}

Responses regarding unwillingness to donate the cornea were also reported by the participants (Table 4). This table shows that religious issues do not appear to prevent the person from donating the cornea as most of the participants disagree that corneal donation contradicts with religion and also that the person has to be religious to donate the cornea. The two most common

Table 2 Characteristics of participants willing to donate their corneas and the influence of study variables (age, gender, level of education, and income) on willingness toward corneal donation

\begin{tabular}{|c|c|c|c|}
\hline \multirow[t]{2}{*}{ Demographics } & \multicolumn{3}{|c|}{ Willingness to donate cornea after death } \\
\hline & Willingness to donate, $\mathbf{N}(\%)$ & Unwillingness to donate, $\mathbf{N}(\%)$ & $P$-value \\
\hline Total & $336(67.2)$ & $159(32.8)$ & \\
\hline Age (years) & & & 0.316 \\
\hline $18-29$ & $195(72.5)$ & $74(27.5)$ & \\
\hline $30-50$ & $120(64.5)$ & $66(35.5)$ & \\
\hline$>50$ & $21(52.5)$ & $19(47.5)$ & \\
\hline Gender & & & 0.363 \\
\hline Male & $142(65.4)$ & $75(34.6)$ & \\
\hline Female & $194(69.8)$ & $84(30.5)$ & \\
\hline Education & & & 0.000 \\
\hline Elementary & $18(41.9)$ & $25(58.1)$ & \\
\hline High school & $76(56.3)$ & $59(43.7)$ & \\
\hline Bachelors & $220(75.9)$ & $70(24.1)$ & \\
\hline Graduate degree & $22(81.5)$ & $5(I 8.5)$ & \\
\hline Income (JOD) & & & 0.438 \\
\hline$<500$ & $174(64.9)$ & $94(35.1)$ & \\
\hline $500-1,000$ & $122(69.3)$ & $54(30.7)$ & \\
\hline$>1,000$ & $40(78.4)$ & II (2I.6) & \\
\hline
\end{tabular}

Abbreviation: JOD, Jordanian Dinar. 
Table 3 Participants' responses regarding willingness to donate the cornea

\begin{tabular}{|c|c|c|c|c|c|}
\hline Reasons for willingness to donate the cornea & $\begin{array}{l}\text { Strongly } \\
\text { agree, } \\
\text { N (\%) }\end{array}$ & $\begin{array}{l}\text { Agree, } \\
\mathbf{N}(\%)\end{array}$ & $\begin{array}{l}\text { Neutral, } \\
\text { N (\%) }\end{array}$ & $\begin{array}{l}\text { Disagree, } \\
\text { N (\%) }\end{array}$ & $\begin{array}{l}\text { Strongly } \\
\text { disagree, } \\
\mathbf{N}(\%)\end{array}$ \\
\hline $\begin{array}{l}\text { Corneal donation is considered to be a gift of vision, } \\
\text { ie, help someone to see again }\end{array}$ & $|7|(50.4)$ & $149(44.0)$ & $8(2.4)$ & $8(2.4)$ & $3(0.9)$ \\
\hline $\begin{array}{l}\text { Organ donation should be promoted in all } \\
\text { countries around the world }\end{array}$ & $176(52.2)$ & $136(40.4)$ & $22(6.5)$ & $\mathrm{I}(0.3)$ & $2(0.6)$ \\
\hline The benefits of corneal donation outweigh the risk & $82(24.3)$ & $133(39.3)$ & $102(30.2)$ & $17(5.0)$ & $4(1.2)$ \\
\hline $\begin{array}{l}\text { Organ donation can be promoted by "presumed } \\
\text { consent" method }\end{array}$ & $58(17.2)$ & $100(29.6)$ & $93(27.5)$ & $59(17.5)$ & $28(8.3)$ \\
\hline $\begin{array}{l}\text { Organ donation can be promoted by objective } \\
\text { appreciation (financial support) to the family of } \\
\text { the deceased }\end{array}$ & $48(14.2)$ & $94(27.8)$ & $54(16.0)$ & $90(26.6)$ & $52(15.4)$ \\
\hline $\begin{array}{l}\text { The life of a person belongs to God and not to his/ } \\
\text { her family }\end{array}$ & $138(40.8)$ & $\mid 40(4 \mid .4)$ & $46(13.6)$ & II (3.3) & $3(0.9)$ \\
\hline
\end{tabular}

Note: aPresumed consent means that the consent for organ donation will be assumed unless the deceased has expressed a wish in life not to be an organ donor.

reasons for unwillingness to donate were the thought that the cadaver will be treated badly and the fear of other organs being taken than the one specified for donation. Around 77 participants addressed the lack of awareness of corneal donation as a reason for their unwillingness to donate the cornea and many reported conflict of interest, ie, fear of not treating the ill person well for another person to live or see in the case of corneal donation.

\section{Discussion}

\section{Awareness and attitudes regarding corneal donation}

Corneal blindness is considered the fourth cause for visual impairment and blindness in Jordan, with corneal transplantation through corneal donation remaining the main treatment for such cases. ${ }^{4}$ The current study showed a good level of awareness and knowledge about corneal donation among the studied population. Similar to our findings, high level of public awareness of corneal donation was also reported in many studies around the world. ${ }^{17,18,21,27}$

It has been reported widely that the demand on healthy corneas exceeds the actual supply of donated corneas. ${ }^{28}$ Likewise, there is also a lack of corneal supply in Jordan as the Director of Jordan Eye Bank has reported, with local corneal donation increasing to meet $65 \%$ of transplant needs in the Kingdom. ${ }^{29}$ The low supply of donated corneas is mainly attributed to person's attitude toward corneal donation, which is mainly affected by ethical, religious, and social issues and suggested to be influenced by lack of public awareness of eye donation and its benefits. ${ }^{17-19,21,25-27}$

The current study reported that $67.2 \%$ of subjects expressed willingness to donate their corneas and the majority of the participants $(82.8 \%)$ encouraged others for corneal

Table 4 Participants' responses regarding unwillingness to donate the cornea

\begin{tabular}{|c|c|c|c|c|c|}
\hline Reasons for unwillingness to donate the cornea & $\begin{array}{l}\text { Strongly agree, } \\
\mathbf{N}(\%)\end{array}$ & $\begin{array}{l}\text { Agree, } \\
\mathbf{N}(\%)\end{array}$ & $\begin{array}{l}\text { Neutral, } \\
\text { N (\%) }\end{array}$ & $\begin{array}{l}\text { Disagree, } \\
\text { N (\%) }\end{array}$ & $\begin{array}{l}\text { Strongly disagree, } \\
\mathbf{N}(\%)\end{array}$ \\
\hline Organ transplantation contradicts with religions & $7(1.4)$ & $12(2.4)$ & $46(9.2)$ & $43(8.6)$ & $54(10.8)$ \\
\hline It is important to be religious to donate your cornea & $2(1.2)$ & II (6.8) & $24(14.8)$ & $65(40.1)$ & $60(37.0)$ \\
\hline The cadaver will be mutilated and treated badly & $29(17.9)$ & $76(46.9)$ & $27(16.7)$ & $15(9.3)$ & $15(9.3)$ \\
\hline $\begin{array}{l}\text { Fear of other organs being taken than the one(s) specified for } \\
\text { donation }\end{array}$ & $40(24.8)$ & $69(42.9)$ & $20(12.4)$ & $17(10.6)$ & $15(9.3)$ \\
\hline Fear of misallocation of the donated organ ${ }^{a}$ & $34(21.3)$ & $51(31.9)$ & $32(20.0)$ & $26(16.3)$ & $17(10.6)$ \\
\hline $\begin{array}{l}\text { Fear of not treating the donor the maximum if they know he/she } \\
\text { is a donor }\end{array}$ & $25(15.5)$ & $67(4 I .6)$ & $31(19.3)$ & $28(17.4)$ & $10(6.2)$ \\
\hline Fear that the religion does not approve organ donation & $12(7.5)$ & $5 \mathrm{I}(3 \mathrm{I} .7)$ & $42(26.1)$ & $27(16.8)$ & $29(18.0)$ \\
\hline Lack of awareness of benefits of donation & II (6.8) & $67(41.4)$ & $42(25.9)$ & $34(21.0)$ & $8(4.9)$ \\
\hline Fear of talking about death and the sanctity of human body & $14(8.6)$ & $60(37.0)$ & $36(22.2)$ & $35(21.6)$ & $17(10.5)$ \\
\hline Existence of conflicts of interests ${ }^{b}$ & $18(10.6)$ & $72(44.4)$ & $36(22.2)$ & $19(11.7)$ & $17(10.5)$ \\
\hline
\end{tabular}

Notes: aMisallocation means to give the organ to recipients who do not deserve it as much, ie, based on their money, social status, position in the society, or their political connections. ${ }^{b}$ Conflict of interests means to kill a person and not treating him/her well for another person to live. 
donation. This number falls within the range presented for other populations $(41.5 \%-85 \%) .{ }^{27,30-32}$ Demographic factors, such as the age of participants, gender, and monthly income did not appear to influence the subjects' willingness to donate their corneas after death. This finding agrees with that reported by Tandon et al, ${ }^{32}$ who found that the socioeconomic status and monthly income did not influence the willingness to donate the cornea. Similar finding was reported by Yew et al, ${ }^{22}$ who reported that only religion and ethnicity influenced the willingness to donate corneas but not gender or age of the participants. This may emphasize on the results reported by McGlade et al that willingness to donate corneas is mainly related to the person's attitude and subjective norms rather than economic or sociodemographic status of the participants. ${ }^{33}$

The current study showed that the level of education was a predictor of awareness and willingness for corneal donation. This is in agreement with a study by Patil et al, who found that the level of awareness among illiterates was significantly lower compared with those who completed higher education. ${ }^{26}$ It is obvious in this regard that knowledge is associated with the level of education the person has achieved. Although Jordan is considered a developing country, it has crossed a milestone in the education sector and efforts have been made to increase the level of public access to schools. This is beneficial in terms of increasing the general awareness of the population regarding health issues associated with organ donation.

\section{Factors influencing the willingness of participants toward corneal donation}

In this study, more than half of the participants $(67.2 \%)$ were willing to donate their corneas after death. Corneal donation was considered as a "gift of sight" by all the willing participants. The motive for corneal donation was being a good person and doing good deeds. On the contrary, $22.8 \%$ of the participants were unwilling to donate their corneas after death. This finding appeared to be related to some ethical, religious, and social factors, which influenced their decision regarding corneal donation.

\section{Ethical issues related to corneal donation}

Several ethical issues were agreed upon among participants. The most commonly cited reason for unwillingness to donate is the fear of treating the cadaver badly. This reason was followed by fear of other organs being taken other than the one specified for donation. The third reason was "misallocation" of the donated organ. That is, to prioritize people with high socioeconomic status or to people who do not deserve the transplant, ie, their medical case is not urgent for transplantation. In other words, the term "favorism" may decide who takes the organ and who does not. This is reflected by the fear of participants to donate their organs and corneas in particular. These issues can be solved by a set of guidelines under the supervision of a team of medical practitioners who can decide the suitability of candidates assigned for transplantation. Therefore, increasing professional performance in hospitals is very important to gaining trust inside and outside the hospital and improving corneal and organ donation rate. ${ }^{34,35}$

\section{Religious and social issues related to corneal donation}

This work has highlighted the knowledge of participants about the relationship between the process of organ donation and religion. It appeared that most of the participants disagreed that organ donation and transplantation contradict with religion, and that the person has to be religious in order to donate. Participants believed that all religions including Islam, Christianity, and Judaism encourage helping and caring for others. Therefore, donating a cornea to a blind person would help that person to see again and live his/ her life normally. In a study by Ali et al, ${ }^{36}$ a significant correlation was reported between the participants' attitude to donate and their knowledge that it is allowed and supported by religion. In Saudi Arabia, the main and strongest influence for organ donation reported by general population was that Islam supported the concept of transplantation through helping others. ${ }^{37}$ Other religions such as Christianity and Judaism also supported organ donation, and Christianity, eg, was reported to be have a positive influence toward organ or corneal donation. ${ }^{38}$

Although not stated clearly in this work, being a member of a family affected the person's actions. The person may have the will to donate but the influence of the parents on the person's decision is beyond his will. Objection by the family was one of the reasons the participants cited for unwillingness to donate in other reports. ${ }^{27}$ This is a very important issue especially in Arab countries such as Jordan where family ties are very strong and the adults obey, consult, and usually agree to what their parents say or decide even when they are above 18 years old. The other argument is concerned with females, who in some cultures inside Jordan are still dominated by their parents or older males in their household. Therefore, their decision to donate the cornea could be influenced by their families. However, many participants (40.8\%) 
agreed that the body belongs to God not to the family and this is why they were willing to donate their corneas. This may indicate the person's autonomy regarding this issue.

Lawlor and Kerridge ${ }^{39}$ suggested another social perspective regarding corneal donation. The authors reported that families of the deceased agreed to donate internal organs but not the external ones that are apparent like the eyes. The reason behind their refusal was mostly due to superficial disfigurement of the dead, ie, disruption of beauty and loss of person identity. The same authors reported that of all body parts, the eyes represent a social interaction among people and this may explain the lower rate of eye donation compared with other organs, eg, kidney, liver, or heart, and the lack of adequate corneal donation to meet the demand. ${ }^{40}$

Basic knowledge of corneal donation and its benefits appeared to have a significant influence in the person's willingness for corneal donation. ${ }^{21,41}$ This was also confirmed by Ackuaku-Dogbe and Abaidoo, ${ }^{42}$ who reported that the main attributor to corneal donation was the awareness and knowledge of the procedure and its benefits.

\section{Conclusion}

To the best of our knowledge, this study is the first study to address attitudes toward corneal donation in Jordan. The study showed that participants demonstrated high level of awareness about corneal donation and most of them were willing to donate their corneas. The main reason for willingness was doing a good deed by helping others. Whereas fear of the body being treated badly was the main reason for unwillingness to donate, the main source of knowledge about corneal donation reported was the media and healthcare personnel and higher levels of education. This study emphasized on the need to implement public educational programs to increase the awareness of corneal donation and to encourage official registration of willing donors. Thereby, this may reduce the misconception related to corneal donation and increase the supply of local donor tissues.

\section{Acknowledgments}

The authors would like to thank all participants for their agreement to take part in this study. This project was carried out as part of "The Research Ethics Education Program in Jordan" and has been supported by NIH grant number (1R25TW010026-01, Al-delaimy, Wael; PI).

\section{Disclosure}

The authors report no conflicts of interest in this work.

\section{References}

1. Pascolini D, Mariotti SP. Global estimates of visual impairment: 2010. Br J Ophthalmol. 2012;96(5):614-618.

2. WHO Website. Blindness and vision impairment prevention: priority eye diseases; 2018. Available from: http://www.who.int/blindness/ causes/priority/en/index8.html. Accessed May 30, 2018.

3. Tabbara KF. Blindness in the eastern Mediterranean countries. $\mathrm{Br} J$ Ophthalmol. 2001;85(7):771-775.

4. Al-Bdour MD, Al-Till MI, Abu-Khader IB. Causes of blindness among adult Jordanians: a hospital-based study. Eur J Ophthalmol. 2002;12(1):5-10.

5. Armitage WJ, Tullo AB, Larkin DF. The first successful full-thickness corneal transplant: a commentary on Eduard Zirm's landmark paper of 1906. Br J Ophthalmol. 2006;90(10):1222-1223.

6. Frigo AC, Fasolo A, Capuzzo C, et al; CORTES Study Group. Corneal transplantation activity over 7 years: changing trends for indications, patient demographics and surgical techniques from the Corneal Transplant Epidemiological Study (CORTES). Transplant Proc. 2015;47(2):528-535.

7. Lichtinger A, Yeung SN, Kim P, Amiran MD, Rootman DS. The era of lamellar keratoplasty, evolving surgical techniques in corneal transplantation: the University of Toronto experience. Can J Ophthalmol. 2012;47(3):287-290.

8. Ple-Plakon PA, Shtein RM. Trends in corneal transplantation: indications and techniques. Curr Opin Ophthalmol. 2014;25(4):300-305.

9. Rezaei Kanavi M, Javadi MA, Motevasseli T, et al. Trends in Indications and Techniques of Corneal Transplantation in Iran from 2006 to 2013; an 8-year Review. J Ophthalmic Vis Res. 2016;11(2):146-152.

10. Zhang AQ, Rubenstein D, Price AJ, et al. Evolving surgical techniques of and indications for corneal transplantation in Ontario: 2000-2012. Can J Ophthalmol. 2013;48(3):153-159.

11. Dandona L, Naduvilath TJ, Janarthanan M, Ragu K, Rao GN. Survival analysis and visual outcome in a large series of corneal transplants in India. Br J Ophthalmol. 1997;81(9):726-731.

12. Thompson RW, Price MO, Bowers PJ, Price FW. Long-term graft survival after penetrating keratoplasty. Ophthalmology. 2003; 110(7):1396-1402.

13. Wroblewski KJ, Mader TH, Torres MF, Parmley VC, Rotkis WM. Longterm graft survival in patients with Down syndrome after penetrating keratoplasty. Cornea. 2006;25(9):1026-1028.

14. Röck D, Wude J, Yoeruek E, Bartz-Schmidt KU, Röck T. Evaluation of Factors Limiting Corneal Donation. Ann Transplant. 2016; 21:701-707.

15. Golchet G, Carr J, Harris MG. Why don't we have enough cornea donors? A literature review and survey. Optometry. 2000;71(5):318-328.

16. Muraine M, Toubeau D, Menguy E, Brasseur G. Analysing the various obstacles to cornea postmortem procurement. Br J Ophthalmol. 2002; 86(8):864-868.

17. Al-Labadi L, Gammoh Y, Shehada R, et al. University students' knowledge of corneal donation and willingness to donate corneas in the occupied Palestinian territory: a cross-sectional study. Lancet. 2018; 391(Supp1 2):S22.

18. Eze BI, Okoye O, Eze JN. Knowledge and attitudes regarding eye donation and corneal transplant: medical versus nonmedical university students in a developing country in Africa. Exp Clin Transplant. 2014; 12(5):454-461.

19. Lawlor M, Kerridge I, Ankeny R, Dobbins TA, Billson F. Specific unwillingness to donate eyes: the impact of disfigurement, knowledge and procurement on corneal donation. Am J Transplant. 2010; 10(3):657-663.

20. Palamar M, Palamar Onay M, Durusoy R, Egrilmez S, Salis O, Yagci A. Public opinion concerning corneal donation and transplant: a survey from Izmir, Turkey. Exp Clin Transplant. 2011;9(2):134-138.

21. Paraz CM, Truong HT, Sai DK, Cajucom-Uy HY, Chan CL, Kassim SM. Knowledge and attitudes toward corneal donation among Singaporean youth: a cross-sectional study. Eye Vis. 2016;3:17. 
22. Yew YW, Saw SM, Pan JC, et al. Knowledge and beliefs on corneal donation in Singapore adults. Br J Ophthalmol. 2005;89(7):835-840.

23. Hermel M, Monhof K, Steinfeld A, et al. The Role of Specifically Tailored Communication Training Among Factors Influencing Consent for Cornea Donation Requested Via Telephone. Transplantation. 2015; 99(10):2223-2229.

24. Krieglstein TR, Neubauer AS, Welge-Lussen U, Priglinger S, Kampik A, Priemer F. Cornea donation. Factors influencing consent. Ophthalmologe. 2001;98(6):545-549.

25. Martin DE, Kelly R, Jones GL, Machin H, Pollock GA. Ethical Issues in Transnational Eye Banking. Cornea. 2017;36(2):252-257.

26. Patil R, Ram Prasath E, Boratne A, Gupta SK, Datta SS. Status of eye donation awareness and its associated factors among adults in rural pondicherry. J Clin Diagn Res. 2015;9(2):LC01-LC04.

27. Gupta A, Jain S, Jain T, Gupta K. Awareness and perception regarding eye donation in students of a nursing college in Bangalore. Indian $J$ Community Med. 2009;34(2):122-125.

28. Crawford AZ, Patel DV, McGhee CNJ. A brief history of corneal transplantation: from ancient to modern. Oman J Ophthalmol. 2013; 6 (Suppl 1):S12-S17.

29. The JordanTimes. Jordan "leading region" in cornea donation, transplants - eye bank; 2014. Available from: http:/www.jordantimes. $\mathrm{com} /$ news/local/jordan-leading-region $\%$ E2\%80\%99-cornea-donationtransplants-\%E2\%80\%94-eye-bank. Accessed July 18, 2018.

30. Dandona R, Dandona L, Naduvilath TJ, McCarty CA, Rao GN. Awareness of eye donation in an urban population in India. Aust NZJ Ophthalmol. 1999;27(3-4):166-169.

31. Ronanki VR, Sheeladevi S, Ramachandran BP, Jalbert I. Awareness regarding eye donation among stakeholders in Srikakulam district in South India. BMC Ophthalmol. 2014;14:25.

32. Tandon R, Verma K, Vanathi M, Pandey RM, Vajpayee RB. Factors affecting eye donation from postmortem cases in a tertiary care hospital. Cornea. 2004;23(6):597-601.
33. McGlade D, McClenahan C, Pierscionek B. Attitudes underlying corneal donation in a group of trainee allied health professionals. PLOS One. 2012;7(12):e53538.

34. Röck D, Petersen P, Yoeruek E, Thaler S, Bartz-Schmidt KU, Röck T. Effect of Organ Scandal on Corneal Donation Rate and Organ Donors at a German University Hospital. Ann Transplant. 2017;22:425-430.

35. Röck T, Bramkamp M, Bartz-Schmidt KU, Röck D. Organ transplantation scandal influencing corneal donation rate. Int J Ophthalmol. 2017; 10(6):1001-1003.

36. Ali NF, Qureshi A, Jilani BN, Zehra N. Knowledge and ethical perception regarding organ donation among medical students. BMC Med Ethics. 2013;14:38.

37. Al-Faqih SR. The influence of Islamic views on public attitudes towards kidney transplant donation in a Saudi Arabian community. Public Health. 1991;105(2):161-165.

38. Hussen MS, Gebreselassie KL, Woredekal AT, Adimassu NF. Willingness to donate eyes and its associated factors among adults in Gondar town, North West Ethiopia. BMC Ophthalmol. 2017;17(1):178.

39. Lawlor M, Kerridge I. Understanding selective refusal of eye donation. Identity, beauty, and interpersonal relationships. J Bioeth Inq. 2014; 11(1):57-64.

40. Lawlor M, Kerridge I. Anything but the eyes: culture, identity, and the selective refusal of corneal donation. Transplantation. 2011;92(11): 1188-1190.

41. Williams AM, Muir KW. Awareness and attitudes toward corneal donation: challenges and opportunities. Clin Ophthalmol. 2018;12: 1049-1059.

42. Ackuaku-Dogbe EM, Abaidoo B. Eye Donation: Awareness and Willingness among Patients Attending a Tertiary Eye Center in Ghana. West Afr J Med. 2014;33(4):258-263.
Clinical Ophthalmology

\section{Publish your work in this journal}

Clinical Ophthalmology is an international, peer-reviewed journal covering all subspecialties within ophthalmology. Key topics include: Optometry; Visual science; Pharmacology and drug therapy in eye diseases; Basic Sciences; Primary and Secondary eye care; Patient Safety and Quality of Care Improvements. This journal is indexed on Submit your manuscript here: http://www.dovepress.com/clinical-ophthalmology-journal

\section{Dovepress}

PubMed Central and CAS, and is the official journal of The Society of Clinical Ophthalmology (SCO). The manuscript management system is completely online and includes a very quick and fair peer-review system, which is all easy to use. Visit http://www.dovepress.com/ testimonials.php to read real quotes from published authors. 